\title{
A Concise Route to the Azaspirodecane Moiety of Halichlorine and Structurally Related Alkaloids.
}

\author{
Andrea L. de Sousa and Ronaldo A. Pilli* \\ Instituto de Química, Universidade Estadual de Campinas, C. P. 6154, \\ 13084-971, Campinas, SP, Brazil. \\ pilli@iqm.unicamp.br
}

\section{Supporting Information}

The reagents and solvents were used without further purification, except when noted otherwise. ${ }^{1}$ For the reactions requiring anhydrous conditions, flame dried glassware and argon atmosphere were used and solvents were previously treated as recommmended. ${ }^{1}$

The reactions were monitored by thin-layer chromatography (Alugram ${ }^{\circledR}$ SIL G/UV 254 sheets) and by gas chromatography (HP 5890 apparatus equipped with HP-5 column (5\% PhMe silicone, $30 \mathrm{~m}$ x 0,53 $\mathrm{mm}$ x 1,3 $\mu \mathrm{m}$ ) under the following conditions: carrier gas $=$ nitrogen, $\mathrm{FID}$ detector, injector temp $=250{ }^{\circ} \mathrm{C}$; detector temp $=280{ }^{\circ} \mathrm{C}$; oven temp $=1 \mathrm{~min}$ at $100{ }^{\circ} \mathrm{C}$, then $10{ }^{\circ} \mathrm{C} / \mathrm{min}$, final temp $=250{ }^{\circ} \mathrm{C}$, detector FID. GC-MS analyses were carried out with a HP 5890/HP 5970 MSD apparatus.

The final products were purified by column chromatography on silica gel (70-230 mesh), flash-colunn chromatography ${ }^{2}$ with Merck 60 silica gel (230-400 mesh).

IR spectra were registered on a Nicolet Impact 410 with the observed absorptions expressed in $\mathrm{cm}^{-1}$.

High resolution mass spectrometry analyses were carried out in a AutospecMicromass-EB apparatus or in a Micromass-Q-Tof (ESI/APCI, positive mode).

The ${ }^{1} \mathrm{H}$ - and ${ }^{13} \mathrm{C}-\mathrm{NMR}$ were measured with a Bruker AC-300P $(300 \mathrm{MHz}, 7.0$ Tesla), Varian Gemini 2000 (300 MHz, 7.0 Tesla) or Varian Inova 500 (500MHz, 11.7 Tesla). $\mathrm{CDCl}_{3}$ was used as solvent and TMS as internal reference. Chemical shifts $(\delta)$ are indicated in ppm and multiplicities as: s, singlet; d, doublet; t, triplet, m, multiplet, dd, double doublet...). Coupling constants $(J)$ are expressed in Hertz.

\footnotetext{
${ }^{1}$ Perrin, D. D.; Armarego, W. L. F. Purification of Laboratory Chemicals, Pergamon Press, New York, $3^{\text {a }}$ ed., 1988.

${ }^{2}$ Still, W. C.; Mitra, A. J. J. Org. Chem. 1978, 43, 2923.
} 


\section{Diester 7}

To a flame dried flask kept under an argon atmosphere was added THF (5 mL), $i$ $\operatorname{Pr}_{2} \mathrm{NH}(0.76 \mathrm{~g}, 1.0 \mathrm{~mL}, 7.5 \mathrm{mmol})$ and $n$-BuLi (1.72 M soln. in hexanes, $4.20 \mathrm{~mL}, 7.00$ mmol, ) at $-78{ }^{\circ} \mathrm{C}$. After stirring $30 \mathrm{~min}$. at $-78{ }^{\circ} \mathrm{C}$, a soln. of amide $\mathbf{1 0}(5.0 \mathrm{mmol}, 0.64 \mathrm{~g})$ in THF (5 mL) was added. After $45 \mathrm{~min}$, a soln of 1-carbomethoxy cyclopentene (9) (5.0 mmol, $0.63 \mathrm{~g}, 0.60 \mathrm{~mL})$ in THF $(5 \mathrm{~mL})$ was added dropwise and the reaction mixture was kept at $-78{ }^{\circ} \mathrm{C}$ for 30 min., followed by the dropwise addition of a soln. of ethyl 4-iodobutanoate (8) $(3.03 \mathrm{~g}, 12.5 \mathrm{mmol})$ dissolved in DMPU (5 mL). The reaction mixture was let to warm up to rt over a $3 \mathrm{~h}$ period, and stirred at $\mathrm{rt}$ for $18 \mathrm{~h}$. The reaction was quenched by the addition of satd. $\mathrm{NH}_{4} \mathrm{Cl}$ soln. $(5 \mathrm{~mL})$. The organic phase was separated, the aqueous phase was further extracted with ethyl acetate $(3 \times 50 \mathrm{~mL})$ and the combined organic extracts were washed with brine $(50 \mathrm{ml})$ and dried over anhydrous $\mathrm{MgSO}_{4}$. The solvent was removed under reduced pressure and the yellow oily residue was purified by column chromatography on silica gel (ethyl acetate/hexanes $=4: 1 \mathrm{v} / \mathrm{v}$ ) to yield diester 7 as a colorless liquid (1.19 g, $3.24 \mathrm{mmol}, 68 \%$ yield).

IR $v_{\max } \mathrm{cm}^{-1}$ (film): 2962, 2877, 1728, 1639, 1435, 1169.

${ }^{1} \mathbf{H}$ RMN (500 MHz, $\left.\mathrm{CDCl}_{3}\right) \delta(\mathrm{ppm}), J(\mathrm{~Hz}): 1.01(3 \mathrm{H}, \mathrm{d}, J=7.0) ; 1.22(3 \mathrm{H}, \mathrm{t}, J=$ 7.2); 1.20-1.29 (1H, m); 1.36-1.46 (2H, m); 1.51-1.64 (3H, m); 1.73-2.02 (8H, m); 2.22 $(2 \mathrm{H}, \mathrm{t}, J=7.2)(1 \mathrm{H}, \mathrm{ddd}, J=12.0,9.2,7.3) ; 2.48(1 \mathrm{H}, \mathrm{dq}, J=9.2$ e 7.0$) ; 3.29-3.4 / 3.59-3.65$ (m), 4H; $3.64(3 \mathrm{H}, \mathrm{s}) ; 4.08(2 \mathrm{H}, \mathrm{q}, J=7.2)$.

${ }^{13} \mathbf{C} \mathbf{R M N}\left(125 \mathrm{MHz}, \mathrm{CDCl}_{3}\right) \delta(\mathrm{ppm}): 14.2,16.9,21.7$ (2C), 24.3, 26.1, 28.7, 34.6, 34.7, 37.3, 38.5, 45.7, 46.0, 51.4, 51.7, 56.7, 60.1, 173.5, 174.6, 176.7.

HRMS (70 eV): $m / z$ calcd. for $\mathrm{C}_{20} \mathrm{H}_{33} \mathrm{NO}_{5}$ : 369.2358; found: 369.2357. 


\section{Amide 13}

A soln. of diester $7(0.25 \mathrm{~g}, 0.68 \mathrm{mmol}$,$) in toluene (5 \mathrm{~mL})$ was added dropwise to suspension of recently sublimed $t$-BuOK $(0.41 \mathrm{~g}, 3.4 \mathrm{mmol})$ in toluene $(15 \mathrm{~mL})$. The mixture was heated under reflux for $5 \mathrm{~min}$. and after cooling down to $\mathrm{rt}$ the reaction mixture was treated with satd. $\mathrm{NH}_{4} \mathrm{Cl}$ soln $(5.0 \mathrm{~mL})$. The phases were separated and the aqueous one was extracted with ethyl acetate $(3 \times 20 \mathrm{~mL})$. The combined organic phases were washed with brine $(20 \mathrm{~mL})$ and dried over anhydrous $\mathrm{MgSO}_{4}$. Evaporation of the solvent under reduced pressure afforded a yellow liquid $(0.17 \mathrm{~g})$ which was used in the next step without further purification.

The yellow liquid above $(0.17 \mathrm{~g})$ was dissolved in THF $(5 \mathrm{~mL})$ and water $(1.0 \mathrm{~mL})$ and conc. $\mathrm{H}_{2} \mathrm{SO}_{4}(0.5 \mathrm{~mL})$ were added. The mixture was heated under reflux for $4 \mathrm{~h}$ and the organic solvent was removed under reduced pressure. The liquid residue was washed with brine $(5 \mathrm{~mL})$ and extracted with ethyl acetate $(3 \times 15 \mathrm{~mL})$. The combined organic phases were treated with brine $(15 \mathrm{~mL})$ and dried over anhydrous $\mathrm{MgSO}_{4}$. The solvent was removed under reduced pressure and the yellow liquid was purified by column chromatography on silica gel (hexanes/ethyl acetate $=3: 7, \mathrm{v} / \mathrm{v})$ to yield amide $13(0.42$ mmol, $0.11 \mathrm{~g}, 61 \%$ yield) as a colorless liquid.

IR $v_{\max } \mathrm{cm}^{-1}$ (film): 2951, 2870, 1724, 1634, 1435, 1242.

${ }^{1} \mathbf{H}$ RMN (300 MHz, CDCl $) \delta(\mathrm{ppm}), J(\mathrm{~Hz}): 1.04$ (3H, d, $\left.J=7.0\right)$; 1.20-2.14 (15H, m); 2.20-2.39 (2H, m); $2.75(1 \mathrm{H}, \mathrm{dq}, J=10.6$ e 7.0$) ; 3.22-3.40 / 3.48-3.59(\mathrm{~m}), 4 \mathrm{H}$.

${ }^{13} \mathbf{C} \mathbf{R M N}\left(75 \mathrm{MHz}, \mathrm{CDCl}_{3}\right) \delta(\mathrm{ppm}): 17.4,20.5,24.4,25.1,26.1,32.3,39.7,39.8$ (2C), 40.2, 45.5, 46.0, 51.7, 57.6, 174.7, 225.4 .

HRMS (70 eV): $m / z$ calcd. for $\mathrm{C}_{16} \mathrm{H}_{25} \mathrm{NO}_{2}: 263.1885$, found:263.1832. 


\section{Lactone 15}

To a soln. of amide $13(0.950 \mathrm{~g}, 3.60 \mathrm{mmol})$ in THF $(20 \mathrm{~mL})$ at $0^{\circ} \mathrm{C}$ and under magnetic stirring, was added $\mathrm{LiEt}_{3} \mathrm{BH}(1.0 \mathrm{M}$ soln. in THF; $3.60 \mathrm{~mL}, 3.60 \mathrm{mmol})$. The reaction mixture was let to warm up to $25{ }^{\circ} \mathrm{C}$ and stirred $1 \mathrm{~h}$ when additional $\mathrm{LiEt}_{3} \mathrm{BH}(1.0$ $\mathrm{M}$ in THF, $10.8 \mathrm{~mL}, 10.8 \mathrm{mmol}$ ) was added under ice bath cooling. After stirring $1 \mathrm{~h}$ at rt, the reaction was quenched with satd. $\mathrm{NH}_{4} \mathrm{Cl}(7.0 \mathrm{~mL})$, followed by the addition of $1.0 \mathrm{M}$ $\mathrm{NaOH}(14 \mathrm{~mL})$. The reaction mixture was extracted with ether $(3 \times 40 \mathrm{~mL})$, and the combined organic extracts were treated with brine $(40 \mathrm{~mL})$ and dried over anhydrous $\mathrm{MgSO}_{4}$. The solvent was removed under reduced pressure to give a yellow oil which was purified by column chromatography on silica gel (hexanes/ethyl acetate $=8: 2, \mathrm{v} / \mathrm{v}$ ) to yield $15(0.699 \mathrm{~g}, 2.41 \mathrm{mmol}, 67 \%$ yield $)$ as a colorless oil and amide $14(0.206 \mathrm{~g}, 0.77 \mathrm{mmol}$, $22 \%$ yield).

\section{Data for lactone 15.}

IR $v_{\max } \mathrm{cm}^{-1}$ (film): 2945, 2864, 1739, 1450, 1352, 1211, 1180 .

${ }^{1} \mathbf{H}$ RMN (500 MHz, $\left.\mathrm{CDCl}_{3}\right) \delta(\mathrm{ppm}), J(\mathrm{~Hz}): 1.19$ (3H, d, $\left.J=6.7\right) ; 1.30-1.41(2 \mathrm{H}$, m); 1.45-1.50 (1H, m); 1.55-1.69 (4H, m); 1.69-1.77 (2H, m); 1.80-1.96 (2H, m); 2.01-2.14 $(2 \mathrm{H}, \mathrm{m}) ; 2.18(1 \mathrm{H}, \mathrm{dq}, J=11.9$ e 6.6$) ; 4.33(1 \mathrm{H}, \mathrm{d}, J=4.6)$.

${ }^{13} \mathbf{C}$ RMN (125 MHz, $\left.\mathrm{CDCl}_{3}\right) \delta(\mathrm{ppm}): 13.8,20.7,25.5,30.6,33.8,37.4,37.8,39.8$, 48.5, 54.3, 86.4, 176.8 .

HRMS (70 eV): $m / z$ calcd. for $\mathrm{C}_{12} \mathrm{H}_{18} \mathrm{O}_{2}: 194.13068$, found: 194.13897 .

\section{Data for alcohol 14.}

${ }^{1} \mathbf{H}$ RMN (300 MHz, CDCl $) \delta(\mathrm{ppm}), J(\mathrm{~Hz}): 1.09(3 \mathrm{H}, \mathrm{d}, J=7.0) ; 1.17-2.02(16 \mathrm{H}$, m); 2.21-2.31 (1H, m); $2.75(1 \mathrm{H}, \mathrm{dq}, J=9.9$ e 7.0); [3.39-3.54 (m) + 3.61-3.69 (m) = 4H]; 3.78-3.88 $(1 \mathrm{H}, \mathrm{m})$.

${ }^{13} \mathbf{C} \mathbf{R M N}\left(75 \mathrm{MHz}, \mathrm{CDCl}_{3}\right) \delta(\mathrm{ppm}): 17.3,18.7,23.3,24.5,26.2,31.2,31.8,33.3$, $27.2,39.4,45.8,46.3,47.2,47.2,53.6,76.1,175.6$. 


\section{Diol 16}

To a soln. of lactone $15(0.460 \mathrm{~g}, 2.37 \mathrm{mmol})$ in THF $(20.0 \mathrm{~mL})$ cooled at $0^{\circ} \mathrm{C}$ and under magnetic stirring was added $\mathrm{LiAlH}_{4}(0.719 \mathrm{~g}, 19.0 \mathrm{mmol})$ portionwise. The suspension was stirred at $\mathrm{rt}$ for $15 \mathrm{~h}$, cooled to $0^{\circ} \mathrm{C}$ and water $(719 \mu \mathrm{L}), 15 \%$ aq. $\mathrm{NaOH}$ soln. $(719 \mu \mathrm{L})$ and water $(2.16 \mathrm{~mL})$ were added successively. Excess anhydrous $\mathrm{MgSO}_{4}$ was added and the mixture was vigorously stirred. After filtration, the solid residue was washed with ethyl acetate and the combined organic phases were evaporated at reduced

presssure to give a yellow oil which was purified by column chromatography on sílica gel (hexanes/ethyl acetate $=1: 1, \mathrm{v} / \mathrm{v})$ to yield diol $16(0.458 \mathrm{~g}, 2.31 \mathrm{mmol})$ in $98 \%$ yield.

IR $v_{\max } \mathrm{cm}^{-1}$ (film): 3360, 1455, 1030 .

${ }^{1} \mathbf{H}$ RMN $\left(300 \mathrm{MHz}, \mathrm{CDCl}_{3}\right) \delta(\mathrm{ppm}), J(\mathrm{~Hz}): 0.86(3 \mathrm{H}, \mathrm{d}, J=6.6) ; 1.23-1.34(2 \mathrm{H}$, m); 1.48-2.10 (12H, m); 3.12 (2H, s largo); $3.32(1 \mathrm{H}, \mathrm{dd} J=10.2$ e 8.4); $3.50(1 \mathrm{H}, \mathrm{dd}, J=$ 10.2 e 4.6$) ; 4.03$ (1H, d, J=3.7).

$\left.{ }^{13} \mathbf{C ~ R M N ~ ( 7 5 ~ M H z , ~} \mathrm{CDCl}_{3}\right) \delta$ (ppm): 14.4, 20.0, 22.4, 25.5, 33.8 (2C), 35.4, 36.0, $45.8,60.5,68.5,78.0$.

HRMS (ES): $m / z$ calcd. for $\mathrm{C}_{12} \mathrm{H}_{23} \mathrm{O}_{2}[\mathrm{M}+\mathrm{H}]^{+}: 199.1698$, found: 199.1744 . 


\section{Silyl Ether from Diol 16}

To a soln. of diol $16(0.025 \mathrm{~g}, 0.13 \mathrm{mmol})$ in $\mathrm{CH}_{2} \mathrm{Cl}_{2}(0.60 \mathrm{~mL})$ was added triethylamine $(0.022 \mathrm{~g}, 0.030 \mathrm{~mL}, 0.22 \mathrm{mmol})$ and DMAP $(10 \mathrm{~mol} \%)$. After cooling to $0^{\circ} \mathrm{C}$, TBDPSCl $(0.063 \mathrm{~g}, 0.060 \mathrm{~mL}, 0.23 \mathrm{mmol})$ was added and the reaction mixture was

stirred at $\mathrm{rt}$ for $18 \mathrm{~h}$. Ethyl acetate $(10 \mathrm{~mL})$ was added and the organic phase was washed with water $(3.0 \mathrm{~mL})$ and brine $(3.0 \mathrm{~mL})$. The organi phase was dried over anhydrous $\mathrm{Na}_{2} \mathrm{SO}_{4}$ and the solvente was removed under reduced pressure to yield a pale yellow liquid which was purified by column chromatography on silica gel (hexanes/ethyl acetate $=95: 5$, $\mathrm{v} / \mathrm{v})$ to yield the corresponding monosilyl ether $(0.053 \mathrm{~g}, 0.12 \mathrm{mmol})$ in $96 \%$ yield.

IR $v_{\max } \mathrm{cm}^{-1}$ (film): 3458, 3060, 2947, 2866, 1468, 1107, 1076.

${ }^{1} \mathbf{H}$ RMN $\left(500 \mathrm{MHz}, \mathrm{CDCl}_{3}\right) \delta(\mathrm{ppm}), J(\mathrm{~Hz}): 0.80(3 \mathrm{H}, \mathrm{d}, J=6.6) ; 1.05(\mathrm{~s}, 9 \mathrm{H})$; 1.25-1.29 (2H, m); 1.48-1.92 (10H, m); 2.02-2.20 (3H, m); 3.31 (1H, dd, J=9.8 e 8.4); 3.42 $(1 \mathrm{H}, \mathrm{dd}, J=9.8$ e 4.6); $4.01(1 \mathrm{H}, \mathrm{d}, J=2.2)$; 7.34-7.45 (6H, m); 7.64-7.69 (4H, m).

${ }^{13} \mathbf{C ~ R M N}\left(75 \mathrm{MHz}, \mathrm{CDCl}_{3}\right) \delta$ (ppm): 13.6, 19.2, 20.1, 22.8, 25.0, 26.9, 33.3, 34.2, $35.8,36.2,45.3,60.5,69.3,78.2,127.5,129.5,133.5,135.5,135.6$.

HRMS (ES): $m / z$ calcd. for $\mathrm{C}_{28} \mathrm{H}_{41} \mathrm{O}_{2} \mathrm{Si}[\mathrm{M}+\mathrm{H}]^{+}:$437.2876, found: 437.2855 . 


\section{Ketone 17}

To a flame dried flask was added $\mathrm{CH}_{2} \mathrm{Cl}_{2}(10 \mathrm{~mL})$ and oxalyl chloride $(0.297 \mathrm{~g}, 204$ $\mu \mathrm{L}, 2.34 \mathrm{mmol})$ under argon atmosphere. The soln. was cooled to $-78{ }^{\circ} \mathrm{C}$ and DMSO (0.305 g, $277 \mu \mathrm{L} 2.0$ equiv, $3.90 \mathrm{mmol}$ ) was added slowly. After $30 \mathrm{~min}$, a soln. of the monosilyl alcohol $(0.850 \mathrm{~g}, 1.95 \mathrm{mmol})$ in $\mathrm{CH}_{2} \mathrm{Cl}_{2}(5 \mathrm{~mL})$ and the reaction mixture was stirred $40 \mathrm{~min}$ at $-78{ }^{\circ} \mathrm{C}$ when triethylamine $(0.789 \mathrm{~g} ; 1.1 \mathrm{~mL}, 7.80 \mathrm{mmol})$ was added and the reaction mixture was let to warm up to rt. After $40 \mathrm{~min}, \mathrm{CH}_{2} \mathrm{Cl}_{2}(60 \mathrm{~mL})$ was added and the soln. was washed with aq. $\mathrm{NaCl}(2 \times 25 \mathrm{~mL}$, brine/water $=1: 1, \mathrm{v} / \mathrm{v})$, followed by water $(20 \mathrm{~mL})$. The organic phase was dried over $\mathrm{Na}_{2} \mathrm{SO}_{4}$ and evaporated under reduced pressure to yield a pale yellow oil which was purified by column chromatography on silica gel (hexanes/ethyl acetate $=96: 4, \mathrm{v} / \mathrm{v})$ to yield $17(0.800 \mathrm{~g}, 1.84 \mathrm{mmol})$ as a colorless oil in $94 \%$ yield

IR $v_{\max } \mathrm{cm}^{-1}$ (filme): 3060, 2952, 2862, 1728, 1462, 1105.

${ }^{1} \mathbf{H}$ RMN $\left(500 \mathrm{MHz}, \mathrm{CDCl}_{3}\right) \delta(\mathrm{ppm}), J(\mathrm{~Hz}): 0.96(3 \mathrm{H}, \mathrm{d}, J=6.1 \mathrm{~Hz}) ; 1.07$ (s, 9H); 1.46-1.57 (3H, m); 1.62-1.98 (10H, m); 2.05-2.12 (1H, m); 3.27 (1H, dd, $J=9.8$ e 5.2); 3.41 (1H, dd, $J=9.8$ e 4.1); 7.37-7.46 (6H, m); 7.61-7.67 (4H, m).

${ }^{13} \mathbf{C}$ RMN (125 MHz, $\mathrm{CDCl}_{3}$ ) $\delta$ (ppm): 15.7, 19.2, 20.1, 24.5, 26.9, 30.6, 36.3, 39.1, 39.2, 39.4, 50.2, 57.5, 68.0, 127.6 (2C), 129.6 (2C), 133.6, 133.8, 135.7 (2C), 223.0.

HRMS (ES): $m / z$ calcd. for $\mathrm{C}_{28} \mathrm{H}_{39} \mathrm{O}_{2} \mathrm{Si}[\mathrm{M}+\mathrm{H}]^{+}: 435.2719$, found: 435.2759 . 


\section{Oxime 18}

To a soln. of ketone $17(0.117 \mathrm{~g}, 0.269 \mathrm{mmol})$ in methanol $(2 \mathrm{~mL})$ was added sodim acetate $(0.090 \mathrm{~g}, 1.10 \mathrm{mmol})$ and hydroxylamine hydrochloride $(0.074 \mathrm{~g}, 1.08 \mathrm{mmol})$. The reaction mixture was stirred at $\mathrm{rt}$ for $48 \mathrm{~h}$ and quenched with phosphate buffer $\mathrm{pH} 7(4 \mathrm{~mL})$. The solvent was removed under reduced pressure and the residue was diluted in $\mathrm{CH}_{2} \mathrm{Cl}_{2}$ (5 $\mathrm{mL})$. The phases were separated and the aqueous phase was extracted with $\mathrm{CH}_{2} \mathrm{Cl}_{2}(3 \times 5$ $\mathrm{mL})$. The combined organic phases were washed with brine $(5 \mathrm{~mL})$, dried over $\mathrm{Na}_{2} \mathrm{SO}_{4}$ and the solvent was removed under reduced pressure. The pale yellow oil was purified by chromatography on silica gel (hexanes/ethyl acetate $=92: 8, \mathrm{v} / \mathrm{v})$ to yield $\mathbf{1 8}(0.105 \mathrm{~g}, 0.233$ mmol) in $88 \%$ yield as a colorless oil.

IR $v_{\max } \mathrm{cm}^{-1}$ (film): 3334, 3070, 2951, 2862, 1462, 1427, 1387, 1107.

${ }^{1} \mathbf{H}$ RMN (300 MHz, $\left.\mathrm{CDCl}_{3}\right) \delta(\mathrm{ppm}), J(\mathrm{~Hz}): 0.93(3 \mathrm{H}, \mathrm{d}, J=6.6) ; 1.06(\mathrm{~s}, 9 \mathrm{H})$; 1.49-1.94 (12H, m); 2.07-2.18 (1H, m); 2.58-2.68 (1H, m); $3.30(1 \mathrm{H}, \mathrm{dd} J=9.9$ e 5.5$)$; 3.43 $(1 \mathrm{H}, \mathrm{dd}, J=9.9$ e 4.8$) ; 7.35-7.43(6 \mathrm{H}, \mathrm{m}) ; 7.62-7.67(4 \mathrm{H}, \mathrm{m})$.

${ }^{13} \mathbf{C} \mathbf{R M N}\left(75 \mathrm{MHz}, \mathrm{CDCl}_{3}\right) \delta(\mathrm{ppm}): 15.1,19.4,21.6,23.8,27.0$ (3C); 28.2, 29.3, 37.0, 40.7, 41.5, 49.5, 55.5, 68.0, 127.4, 129.3, 133.8 (2C), 135.5 (2C), 170.3. 


\section{Lactam 19}

To a soln. of oxime $18(0.150 \mathrm{~g}, 0.334 \mathrm{mmol})$ in pyridine $(1.5 \mathrm{~mL})$ was added tosyl chloride $(0.159 \mathrm{~g}, 0.835 \mathrm{mmol})$ at $\mathrm{rt}$. The reaction mixture was kept at $0{ }^{\circ} \mathrm{C}$ for $49 \mathrm{~h}$ anda aq. $5 \% \mathrm{NaHCO}_{3}$ soln. ( $4 \mathrm{~mL}$ ) was added. The mixture was stirred $1 \mathrm{~h}$ at $\mathrm{rt}$ and extracted with $\mathrm{CHCl}_{3}(3 \times 15 \mathrm{~mL})$. The organic phase was washed with aq. $5 \% \mathrm{NaHCO}_{3}$ soln $(10$ $\mathrm{mL})$, water $(10 \mathrm{~mL})$, aq. $5 \% \mathrm{HCl}(10 \mathrm{~mL})$ and water $(10 \mathrm{~mL})$. The organic phase was dried over $\mathrm{Na}_{2} \mathrm{SO}_{4}$ and the solvent was removed under reduced pressure to yield a pale yellow oil which was purified by column chromatography on silica gel (hexanes/ethyl acetate $=3: 7$, $\mathrm{v} / \mathrm{v})$ to yield $19(0.090 \mathrm{~g} ; 0.20 \mathrm{mmol})$ in $60 \%$ yield as a colorless solid and a mixture of nitriles 20 (0.019 g, $0.050 \mathrm{mmol}, 15 \%$ yield).

\section{Data for lactam 19.}

IR $v_{\max } \mathrm{cm}^{-1}$ (filme): 3186, 3070, 2954, 2930, 1861, 1656, 1470, 1427, 1408, 1112.

${ }^{1} \mathbf{H}$ RMN (300 MHz, $\left.\mathrm{CDCl}_{3}\right) \delta(\mathrm{ppm}), J(\mathrm{~Hz}): 0.91(3 \mathrm{H}, \mathrm{d}, J=6.6) ; 1.06(\mathrm{~s}, 9 \mathrm{H})$; 1.40-1.90 (12H, m); 2.00-2.10 (1H, m); 2.24-2.33 (1H, m); 3.45 (1H, dd $J=9.9$ e 5.8); 3.50 $\operatorname{ppm}(1 \mathrm{H}, \mathrm{dd}, J=9.9$ e 5.5); $6.04(1 \mathrm{H}, \mathrm{s}) 7.33-7.45(6 \mathrm{H}, \mathrm{m}) ; 7.60-7.65(4 \mathrm{H}, \mathrm{m})$.

${ }^{13} \mathbf{C}$ RMN (75 MHz, $\mathrm{CDCl}_{3}$ ) $\delta$ (ppm): 14.9, 18.7, 19.3, 21.6, 26.3, 27.0 (3C), 31.2, $34.3,35,1,42.5,48.5,64.8,67.9,127.5,129.5,133.5,135.5,172.0$.

HRMS (IE, $70 \mathrm{eV}$ ): $\mathrm{m} / z$ calcd. for $\mathrm{C}_{28} \mathrm{H}_{39} \mathrm{NO}_{2} \mathrm{Si}: 449.7501$, found: 434.3778 . 


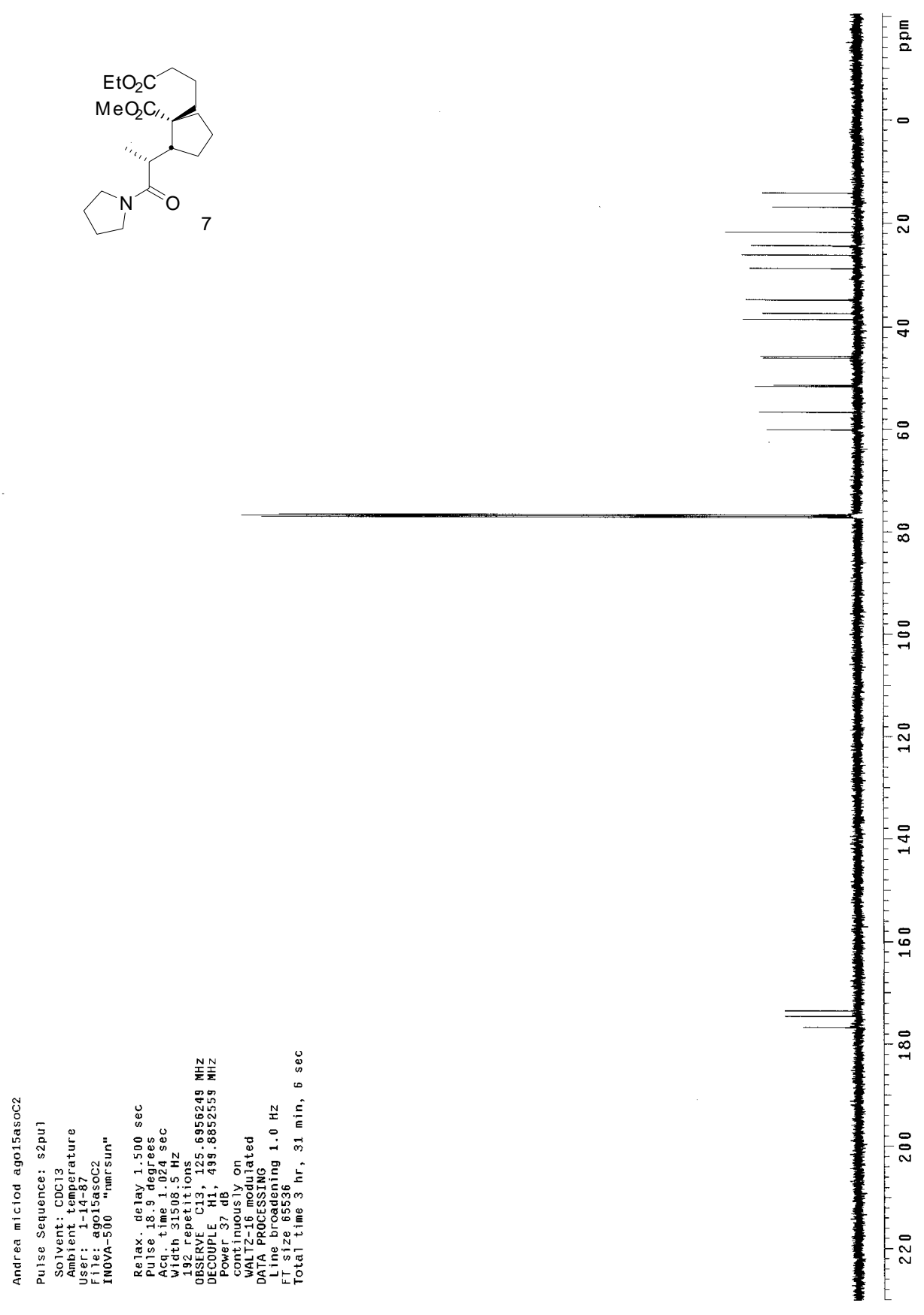



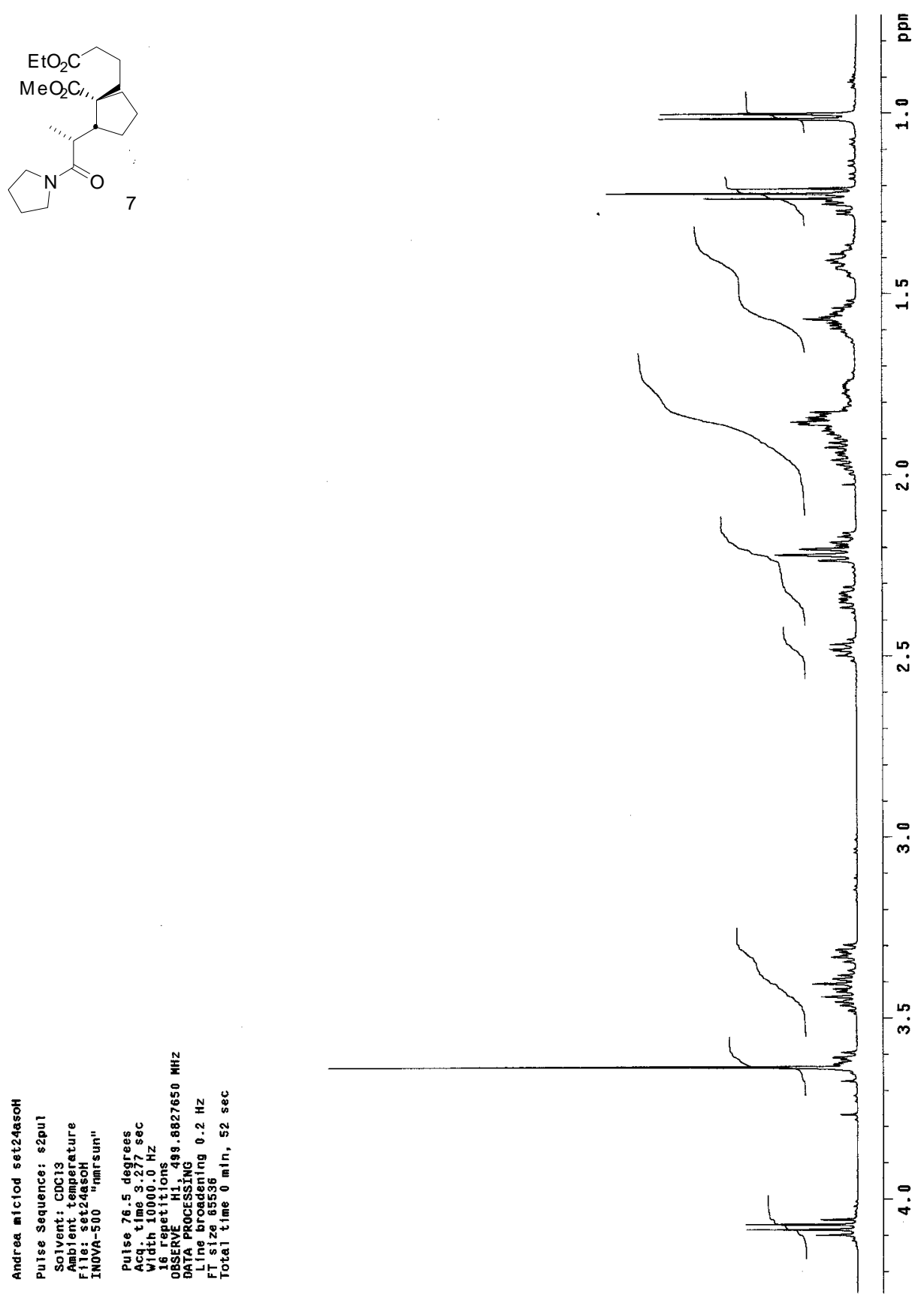


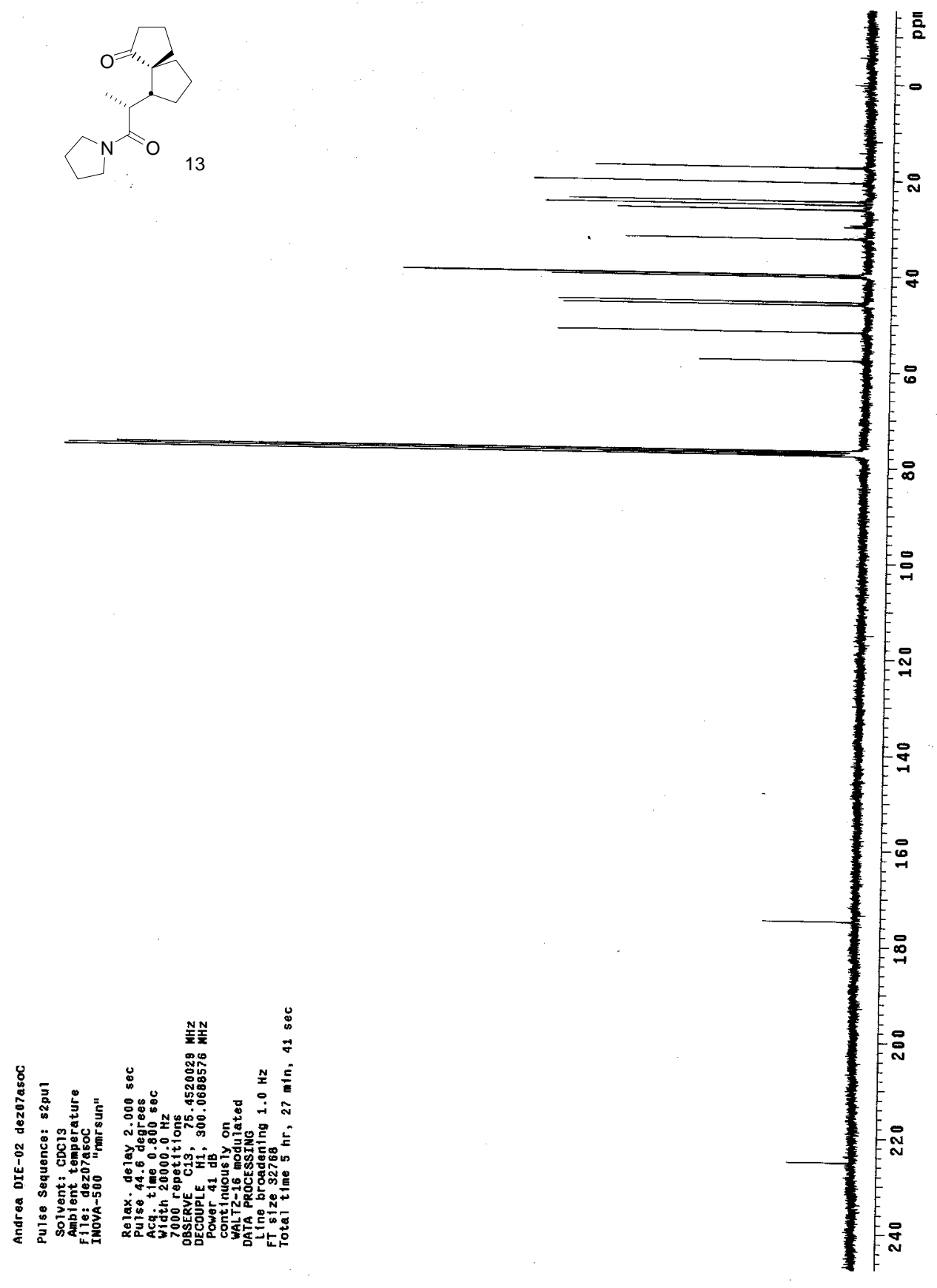



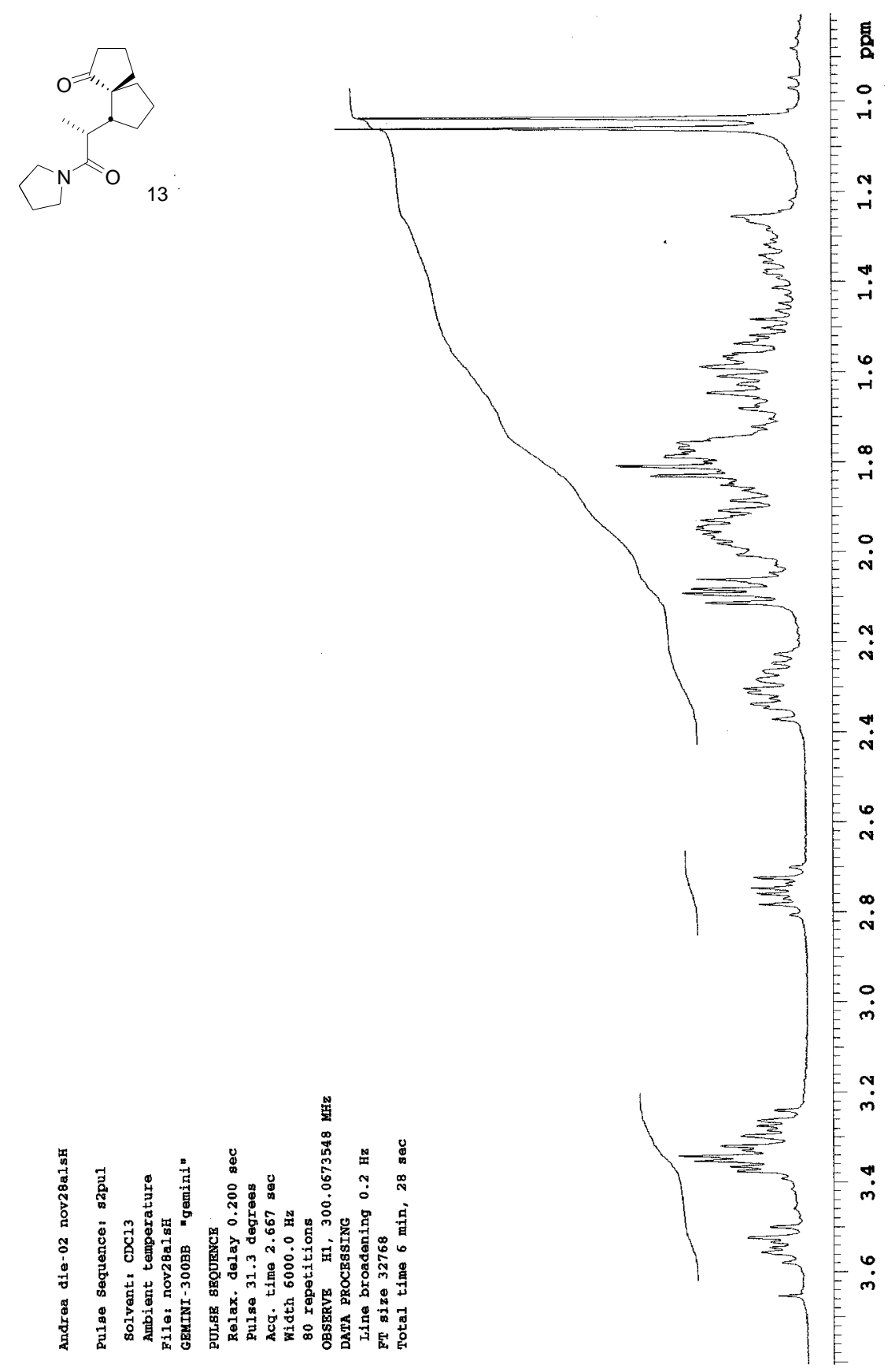


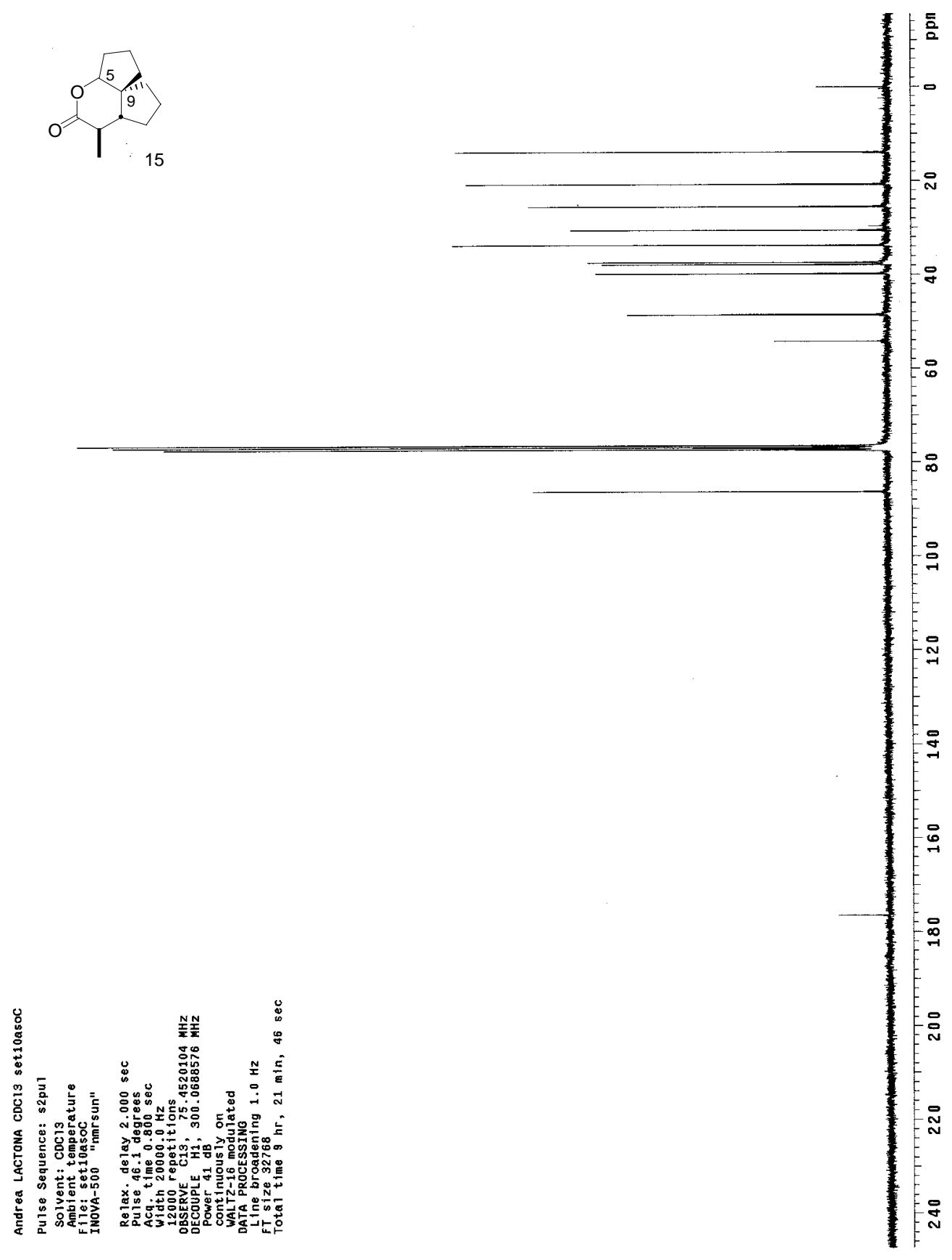




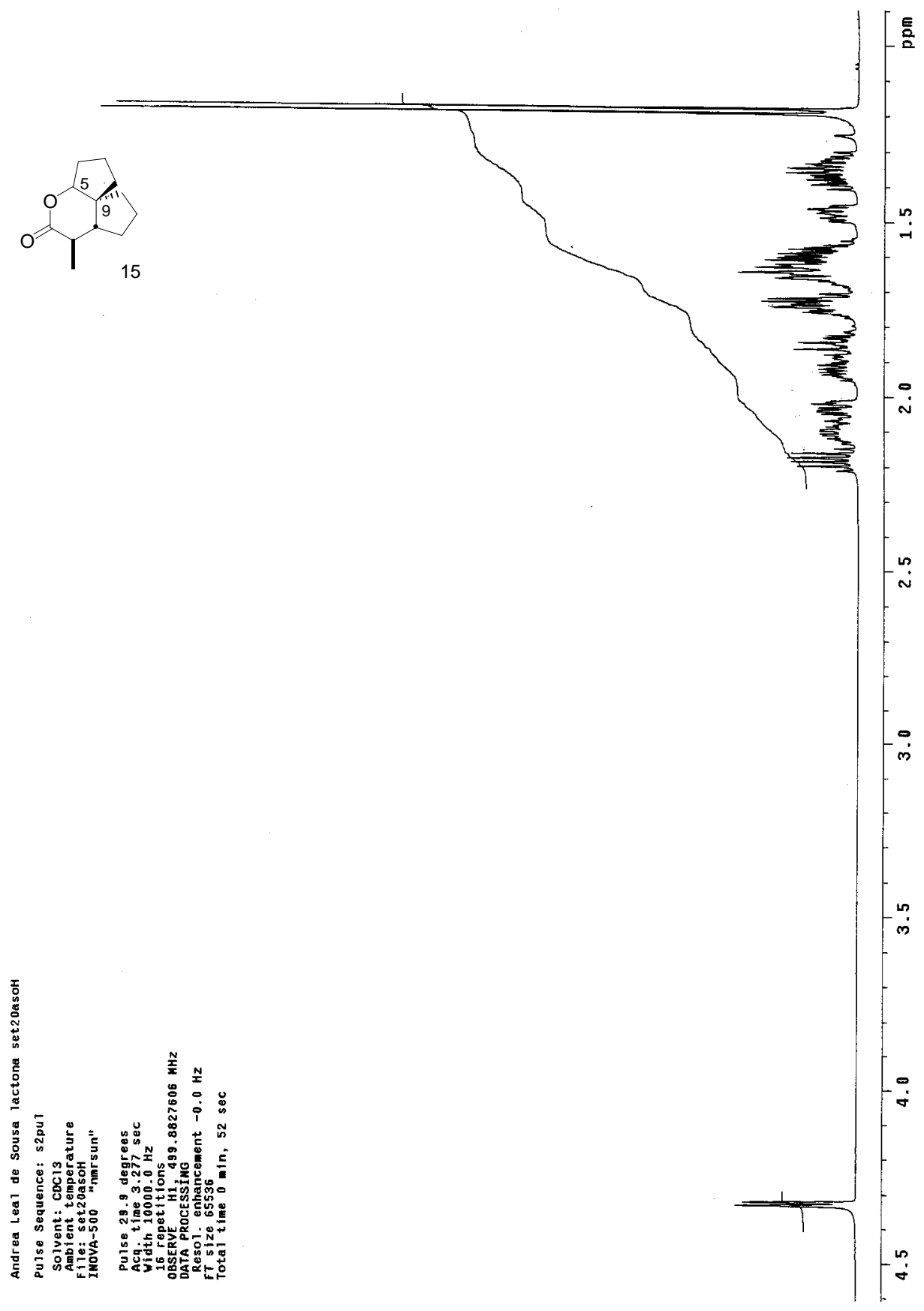



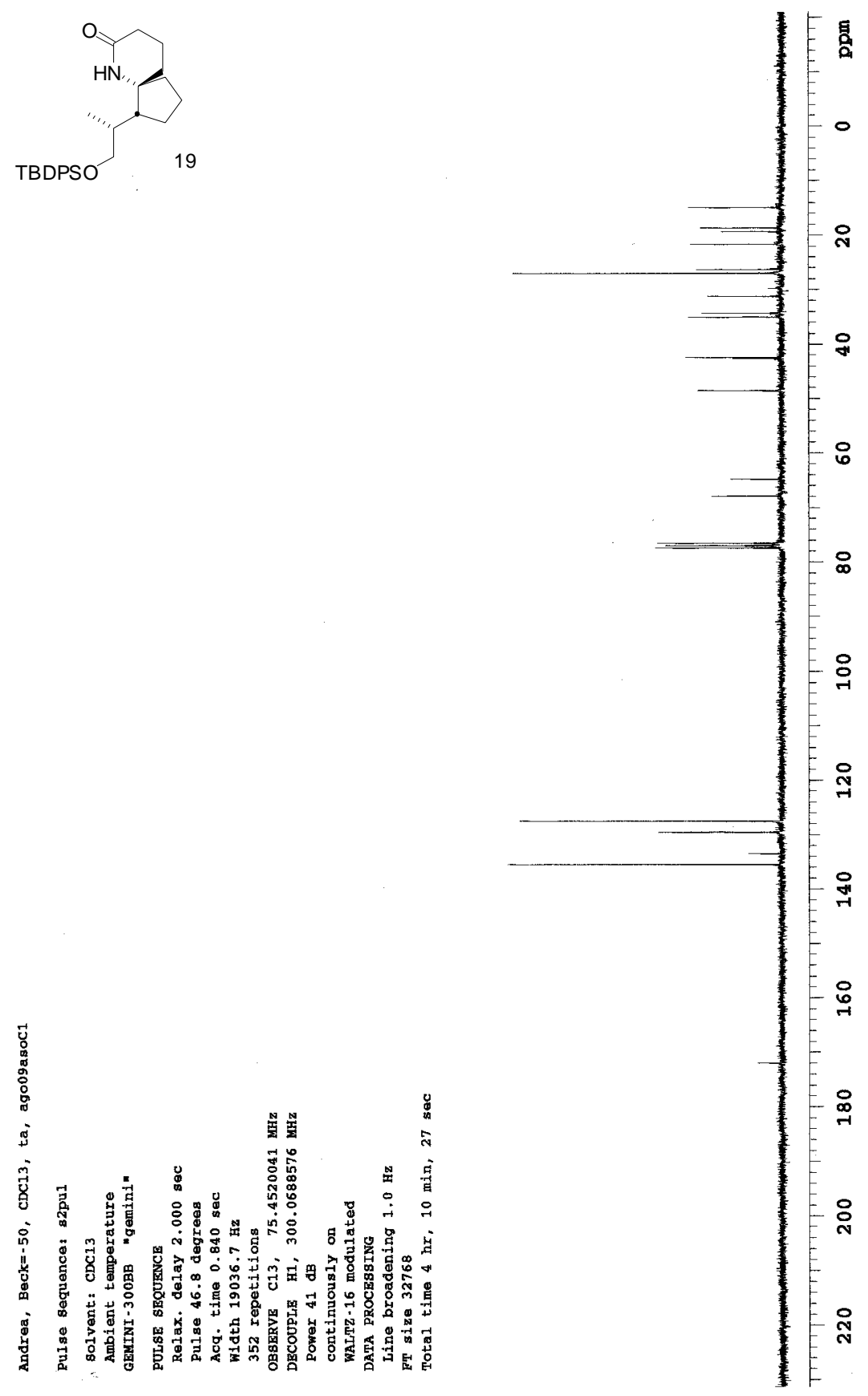


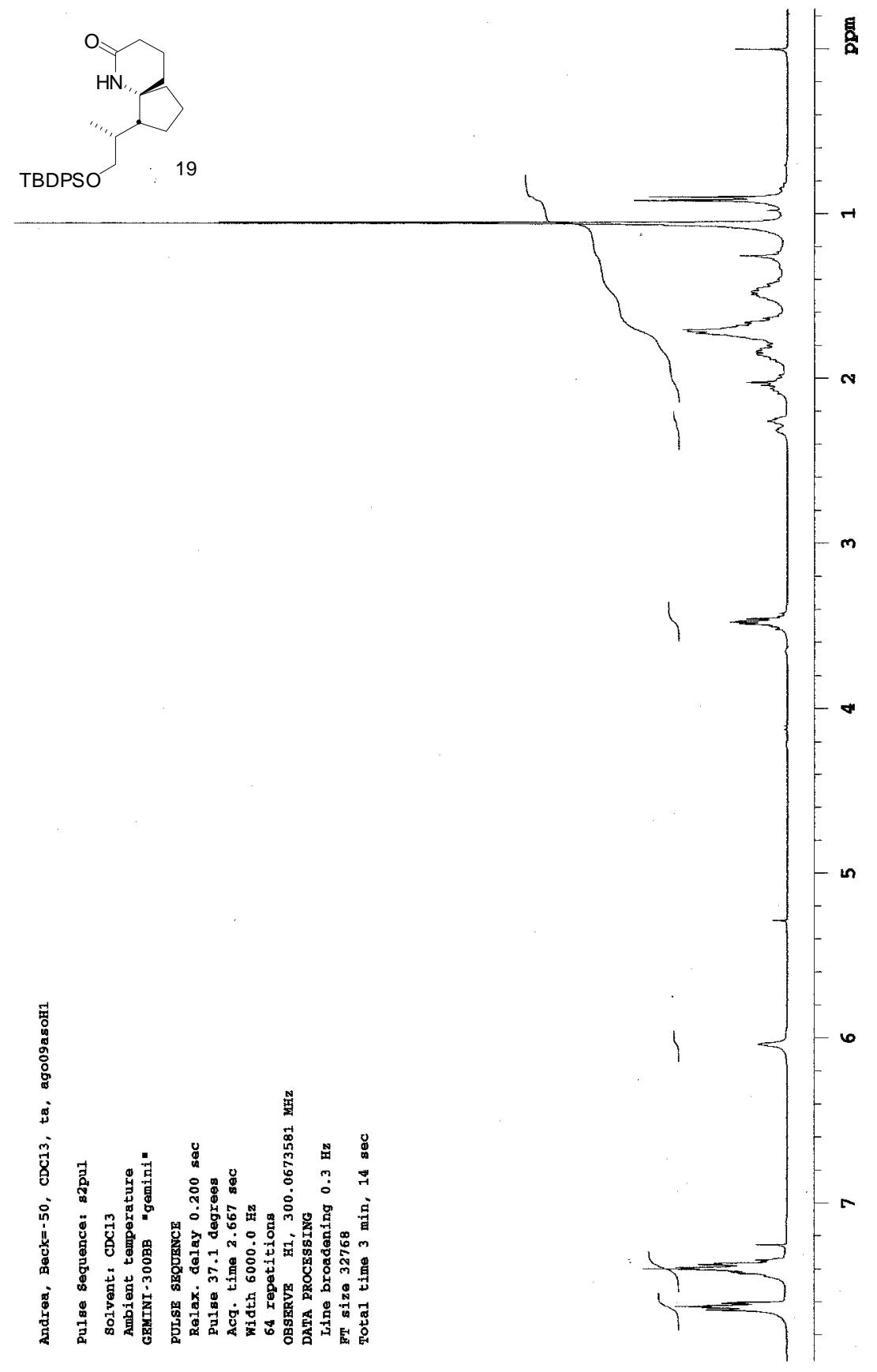

